\title{
ANALISIS EKONOMI TERHADAP PASAL-PASAL HUKUM PERSAING- AN USAHA DALAM UNDANG-UNDANG NOMOR 5 TAHUN 1999
}

\author{
Murni \\ Fakultas Hukum Universitas Trunojoyo Madura \\ (murni_msy@yahoo.co.id)
}

\begin{abstract}
Economic analysis of the law is to see aspects of efficiency in an effort to minimize cost of operations (rules) that the law has been prepared in order to prevent the high cost and inefficient. As the law governing economic matters Competition Act requires the help of other sciences to interpret the meaning of unlawful use of rule of law principle of rule of reason in the Competition Act is an evidentiary process that requires the help of non-legal factors (non-legal factors) such as economics.
\end{abstract}

Keyword : economic, bussines competition, monopoly practices

\begin{abstract}
Abstrak
Analisis ekonomi atas hukum adalah melihat aspek efisiensi dalam upaya meminimalisasi cost terhadap beroperasinya (aturan) hukum yang telah disusun agar tidak menimbulkan ekonomi biaya tinggi dan tidak efisien. Tulisan ini hendak membahas mengenai relevansi penggunaan pendekatan ekonomi terhadap praktik Hukum Persaingan Usaha Sebagai Undang-undang yang mengatur masalah ekonomi Undang-undang Persaingan Usaha memerlukan bantuan ilmu-ilmu lain diluar hukum untuk menginterpretasikan makna aturan hukum Penggunaan prinsip rule of reason dalam Undang-undang Persaingan Usaha merupakan proses pembuktian yang membutuhkan bantuan faktor nonhukum (non legal factor) seperti ilmu ekonomi.
\end{abstract}

\section{Kata Kunci : ekonomi, persaingan usaha, praktek monopoli}

\section{Latar Belakang}

Gagasan untuk menyusun undang-undang yang mengatur tentang persaingan terkait dengan terbentuknya organisasi perdagangan dunia (World Trade Organization) yang telah disetujui oleh Negara Republik Indonesia pada tanggal 15 April 1994 di Marakesh, Marokko. Selanjutnya diratifikasi oleh Indonesia melalui Undangundang Nomor 7 Tahun 1994 tentang Pengesahan Agreement Establishing the World Trade Organization (Persetujuan Pembentukan Organisasi Perdagangan Dunia), maka perlu disusun strategi untuk pembentukan beberapa rancangan undangundang sebagai akibat persetujuan tersebut, diantaranya undang-undang yang mengatur persaingan usaha, yaitu Undang-undang Nomor 5 Tahun 1999 tentang Larangan Praktek Monopoli dan Persaingan Usaha Tidak Sehat ${ }^{1}$

Dasar Pemikiran pembentukan UU Persaingan Usaha hanya 2 (dua) hal, yaitu:

bahwa pembangunan bidang ekonomi harus diarahkan kepada terwujudnya kesejahteraan rakyat berdasarkan Pancasila dan Undang-undang Dasar 1945;

bahwa demokrasi ekonomi menghendaki adanya kesempatan yang sama bagi setiap warga negara untuk berpartisipasi di dalam proses produksi dan pemasaran barang dan atau jasa, dalam iklim usaha yang sehat, efektif, dan efisien sehingga dapat mendorong pertumbuhan ekonomi dan bekerjanya ekonomi pasar yang wajar. ${ }^{2}$

Selanjutnya disebut UU Persaingan Usaha

2 Insan Budi Maulana, Catatan Singkat UU No.5 Th.1999 tentang Larangan Praktek Monopoli dan Persaingan Usaha Tidak Sehat, Citra Aditya Bakti, 2000,h.3-4 
Sebagai salah satu undang-undang yang mengatur bidang ekonomi, maka konsep-konsep yang dikembangkan dalam UU Persaingan Usaha ini banyak menggunakan istilah-istilah dalam ilmu ekonomi, sehingga dalam penerapannya tidak dapat diingkari para penerap hukum persaingan, yaitu KPPU, hakim pengadilan Negeri maupun Hakim Agung) tidak dapat menghindar untuk mempertimbangkan aspek ekonomi dalam memutus perkara persaingan usaha.

Tujuan pembentukan UU Persaingan Usaha, sebagai berikut (Pasal 3 UU Persaingan Usaha):

menjaga kepentingan umum, serta melindungi konsumen;

menumbuhkan iklim usaha yang sehat;

menjamin kepastian kesempatan berusaha yang sama bagi setiap orang;

mencegah praktik-praktik monopoli dan atau persaingan usaha tidak sehat yang ditimbulkan oleh pelaku usaha; serta

menciptakan efektivitas dan efisiensi dalam kegiatan usaha dalam rangka meningkatkan efisiensi ekonomi nasional sebagai salah satu upaya meningkatkan kesejahteraan rakyat.

Bila diamati rumusan tujuan diatas, tampaknya UU Persaingan Usaha tidak hanya menekankan pada masalah menciptakan iklim persaingan usaha dan meningkatkan kesejahteraan rakyat dengan cara melindungi masyarakat dari perilaku pelaku usaha yang monopolistik, tetapi juga hendak meningkatkan efektifitas dan efisiensi aktivitas dunia usaha. Efektifitas dan efisiensi dalam bisnis itulah persoalan yang tidak dapat dipecahkan dari kacamata yuridis. Prinsip efektitas, rasionalitas, dan efisiensi adalah prinsip-prinsip yang dikenal dalam lapangan ilmu ekonomi.

UU Persaingan Usaha sangat membutuhkan penjelasan dari disiplin ilmu ekonomi, karena Undang-undang ini mengatur masalah-masalah ekonomi yang cukup sulit untuk difahami oleh para pelaku usaha dan ahli hukum sendiri tentang apa yang dimaksud dengan beberapa istilah tertentu dalam UU Persaingan Usaha. Adapun Pengaturan UU Persaingan Usaha secara garis besar meliputi hal-hal berikut ini:

Perjanjian yang dilarang;

Kegiatan yang dilarang;
Penyalahgunaan posisi dominan;

Komisi Pengawas Persaingan Usaha;

Tata cara penanganan hukum;

Sanksi-sanksi;

Perkecualian-perkecualian.

Untuk itulah, UU Persaingan Usaha merupakan undang-undang yang berbeda dengan undang-undang lainnya, banyak istilah-istilah non hukum yang digunakan menyusun kalimat dalam pasal-pasal. Sehingga para ahli hukum tidak mudah menafsirkan makna yang terkandung dalam pasal-pasal itu. Dibutuhkan dukungan dari ilmu non hukum untuk menjelaskan dan mengimplentasikannya dalam memutus perkaraperkara persaingan usaha di persidangan.

UU Persaingan Usaha merupakan undangundang yang mengatur bidang ekonomi, maka salah satu bidang yang dapat digunakan untuk menjelaskan kesulitan dalam hukum persaingan adalah ilmu ekonomi, seperti ditegaskan oleh Cooter dan Ulen bahwa: interaksi antara para ahli hukum dan ahli ekonomi telah melahirkan kebijakan pengaturan hukum persaingan (antitrust) dan pengaturan berbagai kebijakan ekonomi negara. Selanjutnya, menurut keduanya bahwa analisis ekonomi terhadap hukum adalah suatu mata pelajaran interdisipliner yang bukan saja menarik bagi peminat hukum dan ekonomi, tetapi juga bagi para peminat kebijakan publik (public policy).

Perkara persaingan usaha merupakan salah satu perkara hukum yang cukup rumit penanganannya dibandingkan perkara hukum lainnya, dimana analisa dari segi ekonomi untuk beberapa perkara sangat diperlukan dalam membantu pada saat melakukan proses pembuktian. Munculnya aliran pemikiran di Amerika Serikat (American Realism) yang bertumpu pada pengamatan terhadap apa yang diputuskan hakim di pengadilan antara lain menjelaskan bahwa banyak faktor non hukum (non legal factor) seperti ilmu ekonomi ${ }^{4}$ yang turut mempengaruhi pertimbangan para hakim dalam memutuskan perkara. Intinya adalah hakim dalam memutuskan perkara tidak semata-mata berdasarkan pertimbangan hukum tetapi membutuhkan adanya faktor non hukum, yang dititik beratkan pada satu pendekatan non

3 Robert Cooter dan Thomas Ulen, Law and Economic, Scott, Foresman and Company, Glenview, Illionis,1998,h.i.

4 Hilaire Mc.Coubrey dan Nigel D.White, Textbook on Jurisprudence, Second Edition, Blackstone Press Ltd.,London, 1996,h.240. 
hukum saja, yaitu pendekatan ekonomi.

Menurut Posner "bahwa penggunaan prinsipprinsip Ilmu Ekonomi dalam penggunaan hukum karena "....economic is powerful tool for analyzing a vast range of legal question..." selanjutnya dikatakan oleh Polinsky bahwa pendekatan ekonomi terhadap hukum dilakukan oleh ahli hukum yang dilakukan dengan maksud "....in order to focus on how to think like an economic about legal rules"'.

Pendekatan yang dilakukan Posner tentunya dapat digunakan dalam mengkaji hukum yang berlaku di Indonesia. Penggunaan teori Economic Analysis of Law yang dikembangkan Richard Posner selain dapat digunakan sebagai alat analisis dalam hukum persaingan juga dapat membantu dalam memecahkan masalah-masalah lingkungan hidup kaitannya dengan perdagangan internasional ${ }^{6}$.

Berdasarkan realitas yang demikian, maka isu hukum yang terkait dengan pendekatan ekonomi dalam hukum persaingan usaha adalah mengenai relevansi penggunaan pendekatan ekonomi terhadap praktik Hukum Persaingan Usaha.

Pembahasan

Analisis Ekonomi Terhadap Hukum

Kajian ekonomi atas hukum, atau yang umumnya dikenal sebagai "Economic Analysis of Law" dianggap muncul pertama kali melalui pemikiran utilitarianisme Jeremy Bentham (1789). Menurut teori ini suatu perbuatan yang baik jika membawa manfaat bagi masyarakat sebagai keseluruhan, yang dirumuskan dalam kriteria perbuatan "the greatest happiness of the greatest number" (kebahagiaan terbesar dari jumlah jumlah orang terbesar $)^{7}$. Munculnya pendekatan ekonomi terhadap hukum pada awal tahun 1960 di Amerika Serikat melalui karya-karya Ronald Coase menulis tentang biaya sosial (The Problem of Social Cost), Guido Calabresi membahas tentang perbuatan melawan hukum (torts) pada awal tahun 1960an. Karya-karya itu mencoba melakukan analisis ekonomi secara sistematis pada masalah-masalah hukum yang tidak ada hubungannya sama sekali dengan pengaturan masalah - masalah ekonomi. ${ }^{8}$ Selanjutnya pendekatan yang benar-benar menjadi teori dalam ilmu hukum setelah Richard Posner menerbitkan bukunya yang berjudul Economic Analisysis of Law pada tahun 1986.

Menurut Posner berperannya hukum harus dilihat dari segi nilai (value), kegunaan (utility) dan efisiensi (efficiency). Posner mendefinisikan efisiensi dengan mengatakan: " . . that allocation of resources in which value is maximized". 9 Selanjutnya Posner mengemukakan pandangannya tentang penggunaan teori ekonomi dalam hukum dengan mengatakan, "many of the doctrines an institution of the legal system are best understood and explained as efforts to promote the efficient of resources' and that "the common law is best... . explained as a system for maximizing the wealth of society". ${ }^{10}$

Maka daya kerja hukum dalam pendekatan ekonomi tidak dapat dilakukan oleh para ahli hukum karena pendekatan ini membutuhkan perhitungan yang cukup rumit. Namun demikian, penggunaan dasar nilai, kegunaan dan efisiensi tidak harus didasarkan pada teori dan perhitungan yang rumit, namun dapat digunakan dengan cara sangat sederhana. ${ }^{11}$ Jadi tergantung dari bagaimana cara ahli hukum menggunakan pendekatan ekonomi tersebut, apakah selayaknya seorang ekonom atau sebagai orang awam.

Dalam pandangan lain, pendekatan ekonomi yang tumbuh dari gerakan realism Amerika Serikat mencoba melihat hukum atau menjelaskan hukum dari pendekatan non hukum seperti ekonomi. ${ }^{12}$ Ilmu Ekonomi adalah hendak mempelajari tentang tingkah laku manusia dalam menghadapi kelangkaan (scarcity) atau keterbatasan sumber daya. Penggunaan sumber-sumber daya (faktor-faktor produksi) harus dilakukan secara rasional dan efisien. Sumber daya dikatakan digunakan secara efisien apabila:

\footnotetext{
5 Hikmahanto Yuwana, Analisis Ekonomi atas Hukum Perbankan, Hukum dan Pembangunan No.1-3 th XXVIII Januari- Juni 1998, h.1

6 Riyanto, Perlindungan Lingkungan Hidup Dalam Perdagangan Internasional:Studi Mengenai Ekspot Indonesia Di Bidang Perikanan dan Kehutanan, Disertasi, Fakultas Hukum Pascasarjana, Universitas Indonesia, Jakarta, 2005, h.20.

7 K.Bertens, Pengantar Etika Bisnis, Kanisius, Yogyakarta, 2000, h.66

8 Richard A.Posner, Economic Analysis Of Law, Fourth Edition, Little Brown and Company, Boston, Toronto, London, 1992,h.25-26.

9 Ibid.,h.11-15.

10 Ibid., h.27.

11 Hikmahanto Yuwana, Bunga Rampai Hukum Ekonomi dan Hukum Internasional, Lentera Hati, Jakarta, 2002, h.3

12 Hilaire Mc.Coubrey dan Nigel D. White, Op.Cit., h.275
} 
seluruh sumber-sumber daya yang tersedia sepenuhnya digunakan, dan

corak penggunaannya adalah sedemikian rupa sehingga tidak terdapat corak penggunaan yang lain yang akan dapat menambah kemakmuran masyarakat. (Dengan kata lain : penggunaannya yang sekarang telah memaksimumkan kesejahteraan masyarakat). ${ }^{13}$

Untuk memahami masalah efisiensi, terdapat dua pengertian efisiensi yang biasanya sering digunakan untuk menilai penggunaan sumbersumber daya, yaitu efisiensi produktif dan efisiensi alokatif $^{14}$.

Analisis ekonomi atas hukum adalah melihat aspek efisiensi dalam penentuan suatu pilihan dalam kehidupan manusia. Konsep tentang pilihan dan rasionalitas mengakibatkan orang harus mengeluarkan biaya karena harus meninggalkan satu pilihan untuk mengejar pilihan lain yang dianggapnya lebih baik. Dalam kaitan ini Robert Cooter dan Thomas Ulen mengatakan bahwa:

Economics provided a scientific theory to predict the effects of legal sanctions on behavior. To economist, sanctions look like prices, and presumably, people respond to these sanctions much as they respond to prices. People respond to higher prices by consuming less of the more expensive good, so presumably people respond to heavier legal sanctions by doing less of the sanctioned activity. Economics has mathematically precise theories (prices theory and game theory) and empirically sound methods (statistics and econometrics) of analyzing the effecs of prices on behavior $^{15}$

Pendapat Robert Cooter dan Thomas Ulen ini memberikan pemahaman bahwa antara dampak harga, baik tinggi atau mahal terhadap perilaku memberikan pengaruh yang sangat signifikan. Hal ini kemudian dikaitkan dengan hukum, berkenaan dengan penerapan sanksi dimana sanksi yang berat atau ringan akan berdampak juga pada perilaku dari orang yang akan menerima saksi tersebut.
Menurut Robert Cooter dan Thomas Ulen pendekatan ekonomi untuk mengevaluasi hukum dan kebijakan, bahwa hukum hendaknya tidak hanya dipandang sebagai suatu teknik berargumen, hukum adalah instrumen untuk mendorong tujuan kepentingan sosial. Agar dapat diketahui bahwa hukum mempunyai tujuan ini, hakim dan para pembentuk hukum lainnya harus mempunyai metode mengevaluasi hukum yang berdampak pada nilai kepentingan sosial. Ilmu ekonomi memprediksi dampak kebijakan pada efisiensi. Efisiensi selalu relevan untuk membuat kebijakan, karena itu selalu lebih baik mendorong setiap kebijakan yang mempunyai biaya rendah daripada biaya tinggi ${ }^{16}$ Jadi yang dimaksud dengan pendekatan dari aspek efisiensi (ekonomi) dalam memandang hukum adalah dalam upaya meminimalisasi cost terhadap beroperasinya (aturan) hukum yang telah disusun oleh para ahli hukum agar tidak menimbulkan biaya ekonomi tinggi, tidak efisien dan tidak rasional ${ }^{17}$ dan itu merupakan tuntutan perkembangan berbagai jenis peraturan (hukum) yang berkaitan dengan bidang ekonomi.

Dalam praktek penerapan pendekatan ekonomi terhadap hukum banyak mendapat pertentangan dari para ahli hukum yang menganut faham positivisme. Alasan mereka didasarkan pada argumentasi bahwa hukum dianggap sebagai peraturan perundang-undangan tertulis yang berisi norma-norma, diantaranya norma keadilan. Pendekatan ekonomi terlalu menekankan pada cost benefit ratio yang terkadang mengabaikan norma keadilan sehingga lahirnya hukum itu justru tidak mendatangkan keadilan bagi masyarakat. Konsentrasi ahli ekonomi yang terfokus pada efisiensi, tidak terlalu merasakan perlunya unsur keadilan (justice). ${ }^{18}$ Dalam perkembangannya analisis ekonomi terhadap hukum ini terus mengalami perkembangan sejalan dengan globalisasi ekonomi yang tak terelakkan, dan salah satu karya dalam kaitan ini adalah analisis ekonomi

\footnotetext{
13 Sadono Sukirno, Pengantar Teori Mikroekonomi, Edisi Kedua, Cetakan Kesepuluh, Raja Grafindo Persada, Jakarta, 1998, h.254

14 Untuk mencapai efisiensi produktif harus dipenuhi dua syarat. Pertama, untuk setiap tingkat produksi ongkos yang dikeluarkan adalah yang paling minimum. Kedua, industri secara keseluruhan harus memproduksi barang pada ongkos rata-rata yang paling rendah. Efisiensi alokatif harus memenuhi syarat: harga setiap barang sama dengan ongkos marginal untuk memproduksi barang tersebut.Ibid.h.12

15 Robert Cooter dan Thomas Ulen, Op.Cit., h.3

16 Ibid.

17 Muchammad Zaidun, Penerapan Prinsip-prinsip Hukum International Penanaman Modal Asing di Indonesia, Disertasi, Program Pascasarjana Universitas Airlangga, Surabaya, 2005, h.35.

18 Michael J. Trebilcock,”Law and Economics,” The Dalhousie Law Journal,Vol.16 No.2 (fall 1993),h. 361-363, dikutip dari Budi Agus Riswandi, Analisis Ekonomi Terhadap Penyelesaian Pelanggaran Hak Cipta Indonesia, diakses 15 April 2009., h.5
} 
terhadap hukum persaingan seperti yang karya Terry Calvani dan John Siegfried yang berjudul Economic Analysis and Antitrust Law.

Analisis Ekonomi Terhadap Pasal-Pasal Hukum Persaingan Usaha dalam UU Persaingan Usaha

Berdasarkan pada 1) ciri-ciri barang yang dihasilkan, 2) banyak perusahaan dalam kegiatan produksi, 3) mudah tidaknya perusahaan baru masuk dalam kegiatan produksi, dan 4) besarnya kekuatan pasar, maka struktur pasar dapat dibedakan dalam 4 (empat) jenis, yaitu pasar persaingan sempurna, monopoli, persaingan monopolistik dan oligopoli

Jika ditinjau dari kerangka hukum persaingan, implementasi UU Persaingan Usaha sangat membutuhkan penjelasan dari disiplin ilmu ekonomi, karena Undang-undang ini mengatur masalah-masalah ekonomi yang cukup sulit untuk difahami oleh para pelaku usaha dan ahli hukum sendiri tentang apa yang dimaksud dengan beberapa istilah tertentu dalam undang-undang, seperti istilah pasar bersangkutan (relevant market), kekuatan pasar (market power), hambatan masuk pasar (barrier to entry), atau masalah harga (price), sementara dalam penjelasan pasal demi pasal tidak dijelaskan istilah ekonomi yang terdapat pada pasal itu, hanya dijelaskan cukup jelas. Jika dilihat jumlah pasal dalam UU Persaingan Usaha, dari 53 pasal ternyata hanya 17 pasal atau 32\% saja yang mendapat penjelasan pasal secara singkat, sedangkan 36 pasal atau $68 \%$ pasal lainnya dijelaskan dengan “cukup jelas” saja.

Kita diingatkan oleh sebuah adagium hukum "interpretation cessat in claris " 19 terhadap 36 pasal tersebut, maka para ahli hukum harus mengakui bahwa itu sangat sulit untuk memahami makna aturan hukum persaingan usaha, oleh karena itu memerlukan bantuan ilmu-ilmu lain diluar hukum untuk menginterpretasikan makna aturan hukum tersebut. Barangkali pembuat Undang-undang hendak menyerahkan kepada hakim, ahli hukum, atau praktisi hukum untuk menginterpresentasikan sendiri apa yang dimaksud dalam pasal-pasal itu. Maka menurut John E. Kwoka, Jr. dan Lawrence
J. White, peran para ahli ekonomi dalam hampir setiap penanganan perkara persaingan usaha memiliki peranan yang cukup penting. (The Antitrust Revolution, 1989) ${ }^{20}$.

Belum lagi, dalam penanganan perkara persaingan usaha juga terkadang melibatkan cukup banyak dokumen yang harus diperiksa, bahkan jumlah halamannya jika ditotal bisa mencapai ribuan hingga ratusan ribu halaman, dan sudah barang tentu membutuhkan waktu, tenaga, serta biaya yang tidak sedikit untuk memeriksanya, dan itu semua membutuhkan cost yang tidak sedikit.

Salah satu bentuk stuktur pasar yang diatur dalam UU Persaingan Usaha adalah monopoli. Monopoli dalam ilmu ekonomi merupakan struktur pasar yang bertentangan dengan pasar persaingan sempurna. Untuk dapat menentukan tingkat produksi dan tingkat keuntungan yang maksimum pada pasar monopoli digunakan dua cara, yaitu: dengan cara pendekatan ongkos total dan hasil penjualan total, dan dengan cara pendekatan ongkos marginal dan hasil penjualan marginal

Dalam hukum persaingan, ketidakefisienan yang lain dalam penegakan UU Persaingan Usaha dapat ditelaah dalam pembentukan Komisi Pengawas Persaingan Usaha (KPPU), Badan Perlindungan Konsumen Nasional (BPKN), dan Badan Penyelesaian Sengketa Konsumen (BPSK) yang dilakukan secara terpisah dan hal ini dapat menimbulkan pemborosan (high cost).. Bandingkan dengan pembentukan lembagalembaga tersebut di Amerika Serikat yang dicakup dalam satu lembaga bernama Federal Trade Commission (FTC) yang memiliki tugas sebagai berikut:

The basic objective of the FTC is to promote free and fair competition in the America Economy. ... It provides guidance to business and industry on what they may do under the laws administered by the commission. It also gathers and makes available to Congress, the President, and the public factual data on economic and business conditions. The FTC consists of five commissioners who are appointed for 7-year terms by the president, with

19 Artinya interpretation stop when a text is clear (interpretasi tidak diperlukan lagi apabila teks sudah jelas), Alfred Reig, Judicial Interpretation of Written Rules, 10 Lousiana Law Review 1979,h.49, 53-65, dikutip dari Mary Ann Glendon et.al: Comparative Legal Tradition, Second Edition, West Publishing Co.St.Paul, Minn, 1994, h.221, Periksa Johnny Ibrahim, Op.Cit., h.23.

20 Dhita Wiradiputra, Hikmah atas Putusan KPPU Temasek, h.2. http://docs.google.com/viewer?a=v\&q=cache:Xe0qlMwJoIsJ:staff.ui.ac.id/ internal/050203007/material/ Diakses 12 Januari 2009. 
the advice and consent of the Senate. Not more than three of the commissioners may be members of he same political party. One commissioner is chosen as chair by the president. The most prominent and active consumer protection agency this year was the Federal Trade Commission ${ }^{21}$

Dengan tugas dan kewenangan yang saling terkait, sehingga hanya dibentuk satu lembaga saja agar tidak terjadi pemborosan (inefisiensi) dalam anggaran belanja negara. Berdasarkan pandangan tersebut, pendekatan aspek ekonomi berkenaan dengan gagasan pembetukan pembentukan lembaga-lembaga hukum penunjang bidang ekonomi, maka harus menjadi pertimbangan penting, agar tidak terjadi inefisiensi dan high cost yang seharusnya dapat dicegah.

Sebagai contoh kasus persaingan usaha IBM dan AT\&T di Pengadilan Amerika Serikat pernah melibatkan kurang lebih satu juta halaman dokumen yang harus diperiksa pengadilan, sehingga menurut Richard Posner (seorang ahli hukum persaingan) prosedur persidangan yang biasa berlaku di Amerika Serikat pada waktu itu tidak mampu menangani permasalahan ini dengan baik sehingga diperlukan mekanisme tersendiri untuk menanganinya (Antitrust Law: An Economic Perspective, 1976). ${ }^{22}$

Hasil penelitian L. Budi Kagramanto menemukan pendekatan ekonomi terhadap hukum persaingan berkaitan dengan penggunaan beberapa istilah ekonomi, seperti relevan market, market power, barrier to entry, penetapan harga (price fixing) ${ }^{23}$. Istilah Relevant Market ini berkaitan erat dengan pengukuran pasar, dan ini dapat digunakan untuk menganalisis adanya tingkat persaingan pada pasar yang bersangkutan. Didalam pasal 1 angka 10 UU Persaingan Usaha diatur tentang pasar yang bersangkutan (relevan market), yaitu "pasar yang berkaitan dengan jangkauan atau daerah pemasaran tertentu oleh pelaku usaha atas barang dan jasa yang sama (sejenis) atau substitusi dari barang dan atau jasa tersebut".

Untuk mendefinisikan pasar relevan, diperlukan 2 (dua) pendekatan, yaitu pertama, pendekatan berdasarkan produk yang diperdagangkan (pasar produk) dan kedua, berdasarkan pada jangkauan geografis (pasar geografis) yang menggambarkan lokasi produksi dari produsen dan penjual. Prinsip pasar produk adalah apakah terdapat produk substitusi yang terdekat (close substitutes) atau tidak dalam pasar. ${ }^{24}$

Close substitutes dapat dicontohkan pada produk minuman Aqua, produk mie instant, atau pulsa ponsel. Jika seandainya produk Aqua telah menaikkan harga sebesar 15\% dan pembeli tidak beralih ke produk lain, maka produk minum air mineral Aqua telah mempunyai penguasaan pasar (market power) yang cukup besar (kuat) dipasar bersangkutan. Kondisi ini dapat dimainkan oleh produsen dengan menaikkan atau menurunkan harga seenaknya sehingga tingkat persaingan menjadi turun, persaingan minuman mineral sudah tidak sempurna lagi, karena Aqua telah berhasil membatasi produk pesaingnya dalam pasar. Keadaan semacam inilah yang dilarang dalam UU Persaingan Usaha.

Seharusnya jika salah satu produk tidak ada atau harganya tidak terjangkau, pembeli biasanya akan beralih pada produk substitusi lain yang sejenis, tetapi jika di pasar tidak tersedia produk substitusi atau harganya tidak terjangkau, maka pembeli menjadi dirugikan. Kenaikan harga produk itu harus kecil namun signifikan supaya tetap terjangkau.

Lain halnya dengan pasar geografis. Pasar geografis merupakan pembagian pasar berdasarkan lokasi satu produk tertentu tempat barang itu diproduksi atau dijual. Apakah untuk pasar domestik, pasar nasional atau pasar global (internasional). Sebagai salah satu contoh, di dalam UU No.5 Tahun 1999 terdapat beberapa pasal yang berkaitan dengan masalah struktur pasar, seperti antara lain: pasal mengenai monopoli, oligopoli, penguasaan pasar, dan posisi dominan. Kemudian apabila otoritas penegakkan hukum persaingan usaha (dalam hal ini KPPU) hendak mengenakan pasal-pasal tersebut kepada pelaku usaha yang diduga telah melanggar UU No.5 Tahun 1999, maka terlebih dahulu KPPU harus dapat menentukan pasar bersangkutan (relevant market) dari pelaku usaha tersebut.

Salah satu hal yang cukup rumit serta membu-

21 CD-ROM Encyclopedia, Microsoft Encarta Reference Suite 2001. 
tuhkan waktu yang tidak singkat adalah menentukan secara tepat mengenai pasar bersangkutan, dimana pasar bersangkutan didefenisikan oleh UU No.5 Tahun 1999, sebagai pasar yang berkaitan dengan jangkauan atau daerah pemasaran tertentu oleh pelaku usaha atas barang dan atau jasa yang sama atau sejenis atau substitusi dari barang dan atau jasa tersebut. Atau dengan kata lain pasar bersangkutan merupakan pasar dimana persaingan berlangsung. Dan untuk menentukannya dilihat dari dua komponen yaitu pasar produk (product market) dan pasar geografis (geographic market).25

Dalam menentukan pasar produk dan pasar geografis biasanya dilakukan melalui serangkaian penelitian empiris yang tidak mudah, dan tidak dapat dilakukan dalam jangka waktu yang relatif singkat. Karena terbatasnya waktu yang tersedia, maka terkadang serangkai penelitian empiris yang seharusnya dilakukan untuk dapat menentukan pasar produk dan pasar geografis tidak dapat dilakukan secara maksimal. Bahkan terkadang penentuan pasar produk atau pasar geografis ini hanya berdasarkan dari pendapat para ahli industri yang bersangkutan, yang terkadang metode yang digunakan kurang sesuai dengan metode yang berlaku dalam ilmu hukum persaingan usaha.

Hasilnya seperti pada kasus Carrefour, KPPU menentukan pasar bersangkutan dari Carrefour adalah pasar Hipermarket, dan pesaing dari Carrefour adalah Giant, Hypermart dan Club Store. Jika seandainya dilakukan penelitian dengan mengikuti pedoman yang ada pada umumnya dalam menentukan pasar bersangkutan sudah barang tentu hasilnya mungkin tidak akan seperti itu. Begitupun dalam putusan Temasek, KPPU mendefenisikan pasar bersangkutan dalam putusannya adalah industri layanan telekomunikasi seluler diseluruh wilayah Indonesia, dan KPPU mengesampingkan layanan Fixed Wireless Acces (FWA) telepon bergerak tetap sebagai salah satu pesaing dari layanan seluler. Sehingga beberapa kalangan menilai penentuan defenisi pasar bersangkutan yang dilakukan sepertinya kurang melihat kepada kenyataan yang ada di lapangan.

Pengertian Market Power (Kekuatan Pasar) ini sangat erat kaitannya dengan pangsa pasar.
Pangsa pasar ini mencerminkan kekuatan pasar dari si produsen dan kekuatan pasar tersebut digunakan untuk mengatur harga supaya kompetitif atau digunakan untuk menghambat proses persaingan (barrier to entry). Adapun cara-cara yang dapat dilakukan untuk pengukuran pangsa pasar adalah dengan nilai uang, satuan penjualan, satuan produksi serta kapasitas produksi. ${ }^{26}$

Untuk mengetahui seberapa besar pangsa pasar yang telah dikuasai oleh pelaku usaha, maka diperlukan pengukuran tersendiri dalam pasar yang bersangkutan guna melihat ada tidaknya posisi dominan yang dimiliki oleh pelaku usaha. Pengukuran yang paling sering digunakan adalah melalui pengukuran penjualan dalam bentuk jumlah penghasilan atau jumlah unit. Ada juga pengukuran pasar ini dilakukan dengan melihat hasil penjualan masa lalu termasuk hasil penjualan yang sedang berlangsung.

Masih ada model pengukuran pangsa pasar dengan melihat kapasitas produk. Jika terdapat suatu perusahaan yang memiliki kapasitas produksi dapat menggunakan kemampuannya untuk menghalangi pelaku usaha lainnya masuk pasar dengan cara membanjiri pasar dengan produk yang dihasilkannya. Dari sisi ekonomi pengukuran pasar dapat menggunakan ratio konsentrasi pasar (market consentration ratio) yang sering disebut dengan CR4 maupun Herfindahl-Herschman Index $(\mathrm{HHI})^{27}$. Kedua metode ini biasa digunakan sebagai instrumen dalam kalkulasi pasar.

Metode CR4 menunjukkan bahwa terdapat pangsa pasar total dari 4 (empat) perusahaan terbesar dalam suatu pasar relevan. Sedangkan metode HHI adalah suatu Indexs, dimana index itu digunakan untuk memperhitungkan seluruh perusahaan yang beroperasi pada pasar bersangkutan. Index ini lazim digunakan oleh perusahaan yang berencana melakukan merger dengan satu atau dua perusahaan yang sejenis atau tidak sejenis.

Contoh penggunaan metode HHI dalam rencana merger 5 (lima) buah perusahaan dalam pasar bersangkutan, yaitu pasar mie instant dengan pangsa pasar masing-masing berikut ini: Perusahaan A menguasai 50\%, B menguasai $10 \%$, C menguasai $5 \%$, D menguasai $5 \%$, dan $\mathrm{E}$ menguasai 30\%. Rumus HHI nya adalah (50 x 
$50)+(10 \times 10)+(5 \times 5)+(5 \times 5)+30 \times 30)$ $=3.550$. Apabila perusahaan A dan B bermaksud untuk melakukan penggabungan (merger), maka konsentrasi akan berubah menjadi HHInya adalah $(60 \times 60)+(5 \times 5)+(5 \times 5)+30 \times 30)=4.500$. Dengan demikian terjadi perubahan terhadap konsentrasi pasar sebesar $=950(4.500-3.550){ }^{28}$

Didalam Hukum Persaingan, terdapat dua prinsip yang digunakan untuk menentukan apakah pelaku usaha telah melanggar undangundang dengan melakukan praktek monopoli dan persaingan usaha tidak sehat atau tidak. Prinsip yang pertama, yang dikenal dengan sebutan per se illegal dan yang kedua, rule of reason. Pada pendekatan per se illegal tidak diperlukan analisis ekonomi dalam mengukur apakah tindakan pelaku usaha yang melanggar UU Persaingan Usaha itu telah menghambat proses persaingan atau tidak. Yang perlu dibuktikan hanya berkenaan dengan perjanjian yang dilakukan oleh pelaku usaha apakah termasuk perjanjian yang dilarang oleh undang-undang atau tidak. Pembuktiannya tidak harus ada perjanjian tertulis, tetapi bisa dengan perjanjian lisan atau kesepakatan-kesepakatan yang cenderung pada tindakan yang dilarang. Sedangkan, didalam pendekatan rule of reason diperlukan analisis ekonomi untuk menentukan apakah tindakan tersebut menghambat atau justru mendorong persaingan usaha yang sehat, pasalpasal yang bersifat rule of reason ini membutuhkan analisis atau pendekatan ilmu ekonomi.

Pasal-pasal yang bersifat rule of reason biasanya ditandai dengan kalimat-kalimat seperti, yang dapat mengakibatkan terjadinya praktek monopoli dan persaingan usaha tidak sehat atau kata-kata diduga atau dianggap. Alasan yang dianggap reasonable dari sisi ekonomi dapat diterima sebagai alasan untuk menilai bahwa seorang pelaku usaha tidak terbukti melakukan tindakan tertentu yang dilarang oleh undang-undang. Disinilah peran ilmu ekonomi untuk membantu menjelaskan kasus-kasus yang melanggar pasalpasal rule of reason seperti rumusan Pasal 17 yang mengatur tentang monopoli.

Adapun ukuran reasonableness dalam menen- tukan perbuatan yang melanggar hukum persaingan adalah:

Akibat yang ditimbulkan dalam pasar dan persaingan;

Pertimbangan bisnis yang mendasari tindakan tersebut;

Kekuatan pangsa pasar (market power);

Alternatif yang tersedia;

Tujuan dari tindakan tersebut ${ }^{29}$

Suatu perbuatan baru dapat dinyatakan bersifat anti persaingan dengan melihat akibat yang ditimbulkan, motif ekonomi yang melekat pada tindakannya, penguasaan pasar yang dimenangkan, ketersediaan barang substitusi dalam pasar dan tujuan tindakan itu apakah untuk mematikan pesaing atau tidak. Jika dinilai secara komperhensif dalam kerangka analisis ekonomi terhadap hukum yang dibangun atas dasar beberapa konsep dalam ilmu ekonomi, masih terdapat efisiensi, rasionalisasi, serta keseimbangan dari tindakan yang dilakukan itu maka tindakan itu masih dapat dibenarkan yang berarti tidak melanggar undangundang.

Analisis ekonomi terhadap hukum yang dibangun atas dasar beberapa konsep dalam ilmu ekonomi, antara lain:

pemanfaatan secara maksimal (utility maximization);

rasional (rasionality); dan

stabilitas pilihan dan biaya peluang (the stability of preferences and opportunity cost) $)^{30}$.

Pada dasarnya suatu monopoli dapat timbul pada suatu pasar tertentu yang bisa berbeda dengan timbulnya suatu monopoli pada pasar yang lainnya. Artinya ada suatu sebab tertentu yang menjadi dasar timbulnya monopoli pada suatu pasar tertentu, inilah yang menentukan apakah pada pasar tersebut terjadi praktik monopoli dan persaingan usaha atau tidak. Didalam UU No.5 Tahun 1999 terdapat beberapa pasal yang berkaitan dengan masalah struktur pasar, seperti antara lain: pasal mengenai monopoli, oligopoli, penguasaan pasar, dan posisi dominan. Kemudian apabila otoritas penegakkan hukum persaingan usaha (dalam hal ini KPPU) hendak mengenakan

28 L.Budi Kagamanto I, Op.Cit.,h.125

29 Ningrim Natasya Sirait, Hukum Persaingan Usaha, UU No5/1999 tentang Larangan Praktek Monopoli dan Persaingan Usaha Tidak Sehat, Pustaka Bangsa, 1999, h.79.

30Edmund M.A.Kwaw, The Guide to Legal Analysis, Legal Mothodology and Legal Writing, Emond Montgomery Publication Ltd.,Toronto, 1992,h.17, dikutip dari Jhonny Ibrahim, Op.Cit.,h.58. 
pasal-pasal tersebut kepada pelaku usaha yang diduga telah melanggar UU No.5 Tahun 1999, maka terlebih dahulu KPPU harus dapat menentukan pasar bersangkutan (relevant market) dari pelaku usaha tersebut. Namun sebagai sebuah lembaga penegakan hukum, sudah barang tentu KPPU menghadapi banyak kendala dan permasalahan dalam melaksanakan tugas dan wewenang yang dimilikinya secara baik, dan salah satunya bersumber dari beberapa kekurangan yang ada di dalam UU No.5 Tahun 1999 khususnya dalam hal ini masalah pengaturan jangka waktu penangan perkara yang dianggap kurang sesuai untuk menangani perkara persaingan usaha yang begitu kompleks. Sehingga jangan sampai demi lebih memberikan jaminan kepastian hukum tetapi keadilan hukum terabaikan, dan juga jangan sampai karena keterbatasan waktu yang ada otoritas penegak hukum persaingan usaha tidak dapat bekerja secara profesional.

\section{Kesimpulan}

Setelah melalui tahapan pembahasan,dapat disimpulkan secara umum tentang analisis ekonomi terhadap hukum persaingan adalah sebagai berikut:

Analisis ekonomi atas hukum adalah melihat aspek efisiensi dalam penentuan suatu pilihan dalam kehidupan manusia. Efisiensi selalu relevan untuk membuat hukum dan kebijakan. Pendekatan dari aspek efisiensi (ekonomi) dalam memandang hukum adalah dalam upaya meminimalisasi cost terhadap beroperasinya (aturan) hukum yang telah disusun oleh para ahli hukum agar tidak menimbulkan biaya ekonomi tinggi, tidak efisien dan tidak rasional.

UU Persaingan Usaha mengatur masalahmasalah ekonomi yang cukup sulit untuk difahami oleh para pelaku usaha dan ahli hukum sendiri tentang apa yang dimaksud dengan beberapa istilah tertentu dalam undang-undang, seperti istilah pasar bersangkutan (relevant market), kekuatan pasar (market power), hambatan masuk pasar (barrier to entry), atau masalah harga (price). Oleh karena itu Hukum Persaingan memerlukan bantuan ilmuilmu lain diluar hukum untuk menginterpretasikan makna aturan hukum tersebut, sehingga pasalpasal yang terdapat istilah ekonomi yang sulit dimengerti oleh ahli hukum dapat dijelaskan dalam penjelasan pasal demi pasal secara lebih detail dan rasional. Proses pembuktian adanya pelanggaran dalam hukum persaingan dapat dilakukan dengan menggunakan prinsip per se illegal dan rule of reason Penggunaan prinsip rule of reason merupakan proses pembuktian yang membutuhkan faktor non hukum (non legal factor) seperti ilmu ekonomi, hal ini berbeda dengan pembuktian yang menggunakan prinsip per se illegal (pendekatan hukum) yang hanya menilai adanya pelanggaran berdasarkan bunyi undang-undang. Oleh sebab itu pengetahuan dan pemahaman hakim dan penegak hukum persaingan tentang ilmu ekonomi sangat mempengaruhi pertimbangan hakim dalam memutus perkara-perkara persaingan.

\section{DAFTAR PUSTAKA}

Bertens,K., 2000, Pengantar Etika Bisnis, Kanisius, Yogyakarta.

Budi Maulana, Insan, 2000, Catatan Singkat UU No.5 Th.1999 tentang Larangan Praktek Monopoli dan Persaingan Usaha Tidak Sehat, Citra Aditya Bakti.

Campbell Black, Henry, 1990, Black's Law Dictionary, $6^{\text {th }}$. Ed. West Publishing Co., St.Paul-Minn, USA.

CD-ROM Encyclopedia, Microsoft Encarta Reference Suite 2001

Cooter, Robert dan Ulen, Thomas, 1998, Law and Economic, Scott, Foresman and Company, Glenview, Illionis.
Fuady, Munir, 1999, Hukum Anti Monopoli, Menyongsong Era Perdagangan Sehat, Citra Aditya Bakti, Bandung.

Hakim, Abdul G.Nusantara dan Harman, Benny K., 1999, Analisa dan Perbandingan Undang-undang Antimonopoli, Alex Media Komputindo Bekerjasama dengan Bank Naskah Gramedia Kelompok Gramedia, Jakarta.

Hilaire Mc., Coubrey dan Nigel D.White, Nigel, Textbook on Jurisprudence, Second Edition

Ibrahim, Johnny, 2007, Hukum Persaingan Usaha, Filosofi, Teori, dan Implikasi 
Penerapannya di Indonesia, Bayumedia Publishing, Malang.

Kagramanto, L.Budi, 2008, Mengenal Hukum

Persaingan Usaha, (Berdasarkan UU No.5 Tahun 1999), Laros, Surabaya.

$\begin{array}{lcc}\text { Persekongkolan } & \text { Tender } & \begin{array}{c}\text { Larangan } \\ \text { (perspektif }\end{array} \\ \text { hukum persaingan usaha), Srikandi. }\end{array}$

Natasya Sirait, Ningrim, 1999, Hukum Persaingan

Usaha, UU No5/1999 tentang Larangan

Praktek Monopoli dan Persaingan Usaha Tidak Sehat, Pustaka Bangsa.

Pakpahan, Normin S., 1994, Pokok-pokok Pikiran Tentang Hukum Persaingan Usaha, Proyek Pengembangan Hukum Ekonomi dan Penyempurnaan Sistem Pengadaan, Proyek ELIPS, Kantor Menko Ekuwasbang, Jakarta.

Posner, Richard A., 1992, Economic Analysis Of Law, Fourth Edition, Little Brown and Company, Boston, Toronto, London.

Riyanto, Perlindungan Lingkungan Hidup Dalam Perdagangan Internasional:Studi Mengenai Ekspot Indonesia Di Bidang Perikanan dan Kehutanan, Disertasi,

Siswanto, Arie, 2004, Hukum Persaingan Usaha, Ghalia Indonesia, Bogor.

Sukirno, Sadono, 1998, Pengantar Teori Mikroekonomi, Edisi Kedua, Cetakan Kesepuluh, RajaGrafindo Persada, Jakarta.

Winardi, 1996, Kamus Ekonomi (Inggris-Indonesia), Cetakan ke XIV, Mandar Madju, Bandung.
Yani, Ahmad dan Wijaya, Guwawan, 1999, Anti Monopoli, Raja Grafindo Persada, Jakarta.

Yuwana, Hikmanto, 1998, Analisis Ekonomi atas Hukum Perbankan, Hukum dan Pembangunan No.1-3 th XXVIII JanuariJuni 1998

Hukum Ekonomi dan Hukum Interna-
sional, Lentera Hati, Jakarta.

Zaidun, Muchammad, 2005, Penerapan Prinsipprinsip Hukum International Penanaman Modal Asing di Indonesia, Disertasi, Program Pascasarjana Universitas Airlangga, Surabaya.

\section{Peraturan Prerundang-Undangan}

Undang-undang Republik Indonesia Nomor 5 Tahun 1999 tentang Larangan Praktek Monopoli dan Persaingan Usaha Tidak Sehat

Undang-undang Republik Indonesia Nomor 17 Tahun 2007 tentang Rencana Pembangunan Jangka Panjang Nasional Tahun $2005-2025$

Internet

Agus Riswandi, Budi, Analisis Ekonomi Terhadap Penyelesaian Pelanggaran Hak Cipta Indonesia, http://www.perfspot. com/docs/doc.asp?id=46110

Wiradiputra, Dhita, Hikmah atas Putusan KPPU Temasek, http://docs.google.com/viewer?a =v\&q=cache:Xe0qlMwJoIsJ:staff.ui.ac.id/ internal/050203007/material/ 